\title{
Bazı Yem Bitkileri Karıșımlarında Farklı Hasat ve Muhafaza Sistemlerinin Yem Kalitesi Üzerine Olan Etkilerinin Belirlenmesi
}

\author{
Yasemin VURARAK ${ }^{1, *}$ (iD) \\ Ahmet INCE \\ *Doğu Akdeniz Tarımsal Araștırma Enstitüsü Müdürlüğü, Adana \\ ${ }^{2}$ Çukurova Üniversitesi Ziraat Fakültesi Tarım Makinaları ve Teknolojileri Mühendisliği Bölümü, Adana
}

\author{
*Sorumlu yazar e-mail (Corresponding author e-mail): yasemin.vurarak@tarimorman.gov.tr \\ Geliș tarihi (Received): 11.10.2017 \\ Kabul tarihi (Accepted): 09.07.2019 \\ DOI: https: $10.21657 /$ topraksu.654760
}

Öz

Bu çalıșma, Akdeniz İklimi koșullarında yetiștirilen iki farklı kıșlık buğdaygil, baklagil karıșımının kaba yem olarak hazırlanmasında, farklı hasat ve muhafaza yöntemlerinin yem kalitesi üzerine etkilerinin belirlenmesi amacıyla yapılmıștır. Araștırmada bitkisel materyal olarak, fiğ + tritikale ve italyan çimi + iskenderiye üçgülü karıșımları kullanılmıștır. Çalıșmada, haylaj, kuru ot balyası ve geleneksel silaj muhafaza yöntemleri ele alınmıștır. Hasat makinası olarak, haylaj ve kuru ot yapımında tamburlu ot biçme makinası ile ezme üniteli diskli çayır biçme makinası, geleneksel silaj yapımında ise ot silaj makinası kullanılmıștır. Buna ek olarak, haylaj yapımında 6 kat sarma sayısı dikkate alınmıștır.

Araștırmada, haylaja ait nispi yem değerinin 2. kalite, kuru ot ve geleneksel silajın ise 3. ve 4. kalite sınıfı içinde yer aldığı belirlenmiștir. En kaliteli ürünün, haylajlarda Çukurova koșullarında fiğ + tritikale karıșımına alternatif olarak yetiștirilebilecek italyan çimi + iskenderiye üçgülü karıșımında, “Ezme Üniteli Diskli Çayır Biçme Makinası" ile alınabileceği belirlenmiștir.

Anahtar Kelimeler: Çukurova, haylaj, kaba yem, kalite, muhafaza

\section{Determination of Effects of Different Harvesting and Storage Systems Feed Quality for Some Forage Mixtures}

\begin{abstract}
This study was conducted to determine effects of different harvesting and storage systems on feed quality for two grass and legume mixtures cultivated in Cukurova Region. The mixtures of caramba + berseem clover and vetch + triticale were used as forage material. In the research, haylage, hay bale and traditional silage methods were examined. Harvesting was achieved by using the mover and disc mover with conditioner for haylage and hay bale and by using silage machine for traditional silage. However, feed quality were obtained for six numbers of wrap in haylage.

In the research, the relative feed value of haylage was qualified in second qualty degree while those of hay bale and traditional silage was in third and fourth quality degree, respectively. It was obtained that the highest quality forage was supplied with the mixture of caramba + berseem clover that can be grown in Cukurova Region as an alternative instead of vetch + triticale mixture harvested by Disc Mover with Conditioner.
\end{abstract}

Key words: Çukurova, haylage, forage, storage, quality

*Doktora tezinden türetilmiștir. 


\section{Giriș}

Hayvancılığın tarım sektörünün gelișmesinde önemli rolü olduğunu ve özellikle küçük ișletmelerin etkinliği ve teknolojiyi kullanım kabiliyetlerinin artmasına paralel olarak değiștiği bilinmektedir. Ayrıca küçük ișletmelerin ucuz ve kaliteli kaba yem olan silo yemlerine yönelmeleri ile ișletmelerin daha ekonomik üretim olanaklarına kavușacaklardır (Bilgen vd., 2005). Dünya ülkelerinde olduğu gibi Türkiye de yem masrafları girdiler içinde ilk sıradadır. Doğu Akdeniz Bölgesi'ne ait bazı illerinde süt sığırcılığı ișletmelerinin girdi analizleri değerlendirilmiștir. Değerlendirme sonucunda, ișletmelerin üretim masrafları içinde değișen masrafların en büyük payı aldığı, bu masraflar içinde yem giderlerinin \%87.86 ile birinci sırada olduğu tespit edilmiștir (Yılmaz vd., 2015). Su içeriği zengin yemlerin kuru ot olarak hazırlanması sırasında doğal bulașık olan bakterilerin ortamdan uzaklaștırılması ve fazla suyun buharlașması için güneș enerjisi kullanılır. Tarla șartlarında, sulu yeșil yemin \%84'lere kadar varabilen neminin \%16'ya kadar düșmesi için gerekli olan kurutma gün sayısını yakalamak her zaman mümkün değildir. Akdeniz Bölgesi genelinde olduğu gibi yağıșlı ve nemli bölgelerde kaliteli kaba yem hazırlamak oldukça zordur. Yağıș ve nem yemin istenen hız ve kalitede kurumasını engellemekte ve daha kurumadan kısa sürede bozulmasına neden olabilmektedir (Kılıç, 2010). Biçilen otların yağmur altında kalmaları gibi fazla güneș altında kalmalarının da bașta karoten olmak üzere besin maddelerinin zarar görmesine neden olur (Baytekin ve Gül, 2009). Baytekin ve Gül (2009) yaptıkları bir çalıșmada baklagil yem bitkilerinden bir olan yonca otunun yağmur altında kalması ile sindirilebilirlik kayıplarının \%12, buğdaygillerde ise \%6 oranlarında düștüğünü bildirerek kurutma probleminin kaba yemlerde en belirgin sorun olduğunu vurgulamıșlardır. Akdeniz Bölgesi'nde erken ilkbahar ve sonbahar yağıșları, yem bitkilerinde kurutma probleminin ortaya çıkmasında bașlıca nedenlerden en önemlisi olduğu söylenebilir. İklim șartlarının her zaman otun kurutulmasına olanak sağlamaması ve geleneksel silaj yapımı için de iyi bir mekanizasyon alt yapısına gereksinim duyulması, farklı kaba yem hazırlama yöntemlerinin tespit edilmesi intiyacını ortaya çıkartmaktadır.

Araștırma, farklı çalıșma konularını içermektedir. Farklı yem bitkisi karıșımlarında, farklı hasat makinalarının ve farklı muhafaza yöntemlerinin, yem kalitesine olan etkilerinin incelenmesi, ana amacı olușturmaktadır. Araștırmada hedef, küçük ișletmelere uygun, yem kalitesi yüksek kaba yem hazırlama mekanizasyon zincirlerini belirleyerek karar vericilere sunulması amaçlanmıștır.

\section{MATERYAL VE YÖNTEM}

Çalıșma iki yıl süresince Adana ili sınırlarında Doğu Akdeniz Tarımsal Araștırma Enstitüsü Müdürlüğü, Doğankent lokasyonunda yürütülmüștür. Bitkisel materyal olarak fiğ + tritikale (FT), italyan çimi + iskenderiye üçgülü (iii) karıșımı kullanılmıștır. Ekimde, üniversal ekim makinası kullanılmıș ve ekim normu fiğ $8 \mathrm{~kg} \mathrm{da}^{-1}$ + tritikale $10 \mathrm{~kg} \mathrm{da}^{-1}$, italyan çimi $1.5 \mathrm{~kg}$ $\mathrm{da}^{-1}+$ iskenderiye üçgülü $1.5 \mathrm{~kg} \mathrm{da}{ }^{-1}$ olacak șekilde ayarlanmıștır. Hasatta $165 \mathrm{~cm}$ iș genișliğinde tamburlu ot biçme makinası, $240 \mathrm{~cm}$ iș genișliğinde ve 6 diskli ezme üniteli diskli çayır biçme makinası ve $135 \mathrm{~cm}$ iș genișliğinde ot silaj makinası, balyalama sırasında rulo balya makinası ve balya sarma makinası konulara göre kullanılmıștır.

Haylaj konularının, kuru ot ve silaj konularına göre kalite değerlerindeki değișimlerin belirlenmesi amacıyla deneme Tesadüf bloklarında bölünmüș parseller deneme desenine göre 2 farklı karıșımda (ii, FT), 5 farklı hasat ve muhafaza sisteminde (S1, S2, S3, S4, S5), 2 yıl süre ile 3 tekerrürlü olarak yürütülmüștür. Haylaj yapımında 6 katlı sarım polietilen kalpama malzemesi ile yapılmıștır. Kuru ot balyaları ortalama olarak 20-25 kg balya-1, haylaj balyaları ise 40-50 kg balya-1 ağırlığında küçük balyalar șeklinde yapılmıștır. Tüm veriler bir paket programı kullanılarak LSD değerine göre gruplara ayrılmıștır (Yurtsever, 1984; Kalaycı, 2005). Buna göre konular;

S1: Tamburlu ot biçme makinası + rulo balya makinası (Kuru ot),

S2: Ezme üniteli diskli çayır biçme makinası + rulo balya makinası (Kuru ot),

S3: Tamburlu ot biçme makinası + rulo balya makinası + balya sarma makinası (Haylaj),

S4: Ezme üniteli diskli çayır biçme makinası + rulo balya makinası + balya sarma makinası (Haylaj) ve

S5: Ot silaj makinası + silaj çukuru (geleneksel silaj) olarak uygulanmıștır

S1 ve S2 konularında, ürün hasadından sonra, yeșil yemin kuru ot olarak balya yapılması durumuna kadar gelmesi; yani KM oranının \%80-85'e kadar 
çıkması beklenmiștir. S3 ve S4 konuları olan haylaj konuları hasattan sonra KM oranları \%40-60 olana kadar soldurulmușlardır. Geleneksel silaj konusu olan S5 konusunda karıșımlar hasat edilmiș ve \%25-30 KM civarlarında gelene kadar soldurma ișlemi yapılmamıștır. Tüm ișlemlerin yapılmasından 60 gün sonra silaj, haylaj ve kuru ot konularından örnekler alınarak kalite değerlendirilmesi yapıımıștır.

\section{Tarımsal ișlemler}

Ekimler, iki yılda da Kasım ayı içinde yapılımıștır. Deneme alanında Eylül ayı içinde derin çizel, diskaro ve 1-2 kez rototiller kullanılarak tohum yatağı hazırlanmıștır. Her iki karıșım içinde ekimden önce saf $5 \mathrm{~kg}$ azot ve $5 \mathrm{~kg}$ fosfor gelecek șekilde 20:20 gübresi tabana uygulanmıștır (DATAEM, 2016). Deneme hasatları, Nisan ayı sonunda tamamlanarak konulara göre ürünler muhafaza edilmișlerdir. Illk yıl yağıșların yetersiz olmasından dolayı ilki çıkıș, ikincisi çiçeklenme döneminde olmak üzere 2 kez yağmurlama sulama yapılımıștır. Denemenin ikinci yılında mevsim yağıșları yeterli olduğundan sulama yapılmamıștır.

\section{Ölçümler}

KM hesaplanması Kutlu (2008), ADF, NDF hesaplamaları Anonim (2016), HP analizi Anonim (2002). SKM, KMT ve NYD hesaplanması ise Yavuz vd. (2009), Mayouf ve Arbounche (2014) tarafından bildirilen metotlara göre yapılmıștır. Kaba yemlerin kalite değerlendirmelerinde "Buğday ve Baklagil Yem Bitkileri İçin Kalite Standartları" olarak kullanılan ve Ball vd., (1996); Mayouf ve Arbouche, (2014); Russell (2014) tarafindan belirlenmiș olan sınıflandırma sistemine göre yapılımıștır.

\section{BULGULAR VE TARTIȘMA}

Yıllar $x$ uygulamalar etkileșiminin verim üzerine etkisi önemli bulunmuștur. Fakat yıllar arasındaki farkllığın çevresel ve iklimsel faktörlerden, özelliklede ilk yıl yașanan kuraklıktan kaynaklandığı tahmin edilmektedir. Yıllar itibariyle fark olduğu istatistiki olarak belirlenmiș ancak, her yıl konu sıralamalarında bir değișiklik olmamıștır. İki yıl için yapılan homojenlik testine göre verilerin homojen olduğu tespit edilmiș ve yıl birleștirmesi yapılarak veriler istatistiki olarak değerlendirilmiștir.

Çizelge 1'de balya ağırlık ve yoğunluğu bakımından yapılan değerlendirmede, ii karıșımının balya ağırlığının FT karıșımına göre \%13.2, yoğunluğunun ise \%12.5 oranında daha yüksek olduğu tespit edilmiștir. Ancak, S5 konusuna ait yoğunluk değerinin S3 ve S4 konularına göre 1.61-1.81 kat arasında daha fazla olduğu tespit edilmiștir. S1 ve S2 konuları olan kuru ot konuları ise ortalama olarak S3 ve S4 konularına göre \%57.6, S5 konusuna göre ise \%75.2 oranında daha düșük yoğunluğa sahip oldukları tespit edilmiștir.

Muhafaza yöntemi ve karıșıma göre balya ağırıklarının değiștiği belirlenmiștir. Balya ağırlığı üzerinde istatistiki olarak $p<0.01$ önem seviyesinde karıșımın ve hasat tekniği-muhafaza konularının etkili olduğu belirlenmiștir. Benzer durumun yoğunluk değerleri içinde geçerli olduğu Çizelge l'de görülmektedir. İkili etkileșimlerinde, "karıșım x hasat tekniği ve muhafaza" etkileșimlerinin balya ağırlığı ve yoğunluğu üzerinde istatistiki anlamda ve $p<0.01$ önem seviyesinde etkisinin olduğu belirlenmiștir.

Çizelge 1. Balya ağırlığı ve yoğunluğuna ait varyans analiz tablosu

Table 1. Variance analysis of bale weight and density.

\begin{tabular}{|c|c|c|}
\hline PARAMETRELER & Balya ağırlığı (kg balya-1) & Yoğunluk $\left(\mathrm{kg} \mathrm{m}^{-3}\right)$ \\
\hline \multicolumn{3}{|l|}{ KARIȘIM } \\
\hline ii & $30.50 a$ & 317.09а \\
\hline FT & $25.61 \mathrm{~b}$ & $225.79 \mathrm{~b}$ \\
\hline \multicolumn{3}{|l|}{ HASAT TEKNIĞi ve MUHAFAZA } \\
\hline 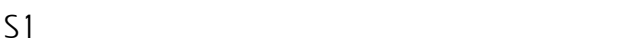 & $17.10 c$ & $120.07 d$ \\
\hline S2 & $18.65 c$ & $132.52 d$ \\
\hline S3 & $35.86 b$ & $280.13 c$ \\
\hline S4 & $40.61 a$ & $315.36 b$ \\
\hline S5 & - & $509.14 a$ \\
\hline $\mathrm{CV}$ & 7.16 & 21.1 \\
\hline Karıșım & $* *$ & $* *$ \\
\hline Hasat tekniği ve muhafaza & ** & ** \\
\hline Karıșım x hasat tekniği ve muhafaza & ** & ** \\
\hline
\end{tabular}


Çizelge 2. Bazı kalite parametrelerine ait varyans analizleri

Table 2. Variance analysis of some quality parameters.

\begin{tabular}{|c|c|c|c|c|c|c|}
\hline PARAMETRELER & $\mathrm{KM}(\%)$ & $\mathrm{pH}$ & ADF $(\%)$ & NDF $(\%)$ & $\mathrm{HP}(\%)$ & $\mathrm{HK}(\%)$ \\
\hline \multicolumn{7}{|l|}{ KARIȘIM } \\
\hline ii & $59.30 b$ & 5.36 & $41.03(3)$ & $55.47 \mathrm{~b}(3)$ & $11.68 a(3)$ & $11.73 a$ \\
\hline FT & $63.47 a$ & 5.34 & $40.69(3)$ & $56.84 a(3)$ & $8.44 \mathrm{~b}(4)$ & $9.36 \mathrm{~b}$ \\
\hline \multicolumn{7}{|l|}{ HASAT TEKNIĞi- MUHAFAZA } \\
\hline S1 & $89.36 a$ & $5.91 a$ & $43.64 a(4)$ & $59.2 \mathrm{a}(3)$ & $9.32 c(4)$ & $9.57 b$ \\
\hline S2 & 89.93a & $5.69 b$ & $40.73 b(3)$ & $56.01 \mathrm{~b}(3)$ & $9.59 \mathrm{bc}(4)$ & $9.88 \mathrm{~b}$ \\
\hline S3 & $49.89 \mathrm{~b}$ & $5.70 b$ & $38.60 c(2)$ & $54.31 c(3)$ & 10.23ab(3) & $10.76 b$ \\
\hline S4 & $49.79 \mathrm{~b}$ & $5.11 \mathrm{C}$ & $36.55 d(2)$ & $53.19 c(2)$ & 10.33ab(3) & $9.86 \mathrm{~b}$ \\
\hline S5 & $27.94 \mathrm{C}$ & $4.36 d$ & 44.77a(4) & $58.14 a(3)$ & 10.83a(3) & $12.66 a$ \\
\hline$C V(\%)$ & 2.3 & 5.7 & 3.64 & 3.8 & 11.0 & 12.8 \\
\hline Karıșım & $* *$ & ÖD & ÖD & * & $\star *$ & $\star *$ \\
\hline Hasat tekniği-muhafaza & $* *$ & $* *$ & $* *$ & ** & * & ** \\
\hline Karıșımxhasat tekniăi ve muhazafa & ** & ÖD & ÖD & ** & ÖD & * \\
\hline
\end{tabular}

${ }^{*} \mathrm{p}<0.05 ;{ }^{* *} \mathrm{p}<0.01$ hata sınırları içinde önemlidir, ÖD: Önemli değil; il: İtalyan çimi + iskenderiye üçgülü karıșımı, FT: Fiğ + tritikale karıșımı; S1:Tamburlu ot biçme (Kuru ot), S2:Ezme üniteli diskli çayır biçme (Kuru ot), S3:Tamburlu ot biçme (Haylaj), S4:Ezme üniteli diskli çayır biçme (Haylaj), S5: Ot silaj (silaj); (1, 2, 3, 4, 5): kalite sınıfı.

Çizelge 2 incelendiğinde, S3 ve S4 konularına ait Ph, ADF ve NDF değerinin S1 ve S2 konularına göre düșük olduğu, HP değerinin ise $\$ 1$ ve $\$ 2$ konularına göre oldukça yüksek, S5 konusu ile de yaklașık olarak aynı düzeyde olduğu belirlenmiștir. Çizelge 3 de SKM, KMT ve NYD bakımından bir değerlendirme yapıldığında, tüm konular arasında ürünün hangi karıșım olduğuna bakılmaksızın S4 konusundan en iyi kalitede ürün alındığı ve istatistiki olarak diğer konulardan $p<0.01$ önem düzeyinde farklılık gösterdiği belirlenmiștir. Haylaj ile geleneksel silajın NYD arasında \%18.8 oranında fark olduğu tespit edilmiștir. Ball vd. (1996), Mayouf ve Arbouche (2014), Russell (2014) tarafindan kullanılan buğdaygil ve baklagil yembitkileri için kalite standartlarına göre bir değerlendirme yapıldığında öne çıkan konu \$4 konusunun 2. kalite sınıfında yer aldığı belirlenmiștir. En iyi ürünün elde edilmesinde bu sistemin kullanılmasının üreticiler açısından faydalı olacağını söylemek mümkündür.

Çalıșmada, S4 sistemi kullanılarak tüm ürünlerin muhafazası bölge ve benzer iklim tipine sahip diğer bölgelerde de rahatıkla kullanılabileceği tespit edilmiștir. Polak ve Jancovo (2006), çalıșmalarında iki farklı șartlandırıcılı/koșullandıcılı tip (metal ve plastik parmaklı) ot biçme makinasını çayır otlarında denemișler ve plastik parmaklı tip șartlandırıcılarla biçilen otların protein değerinin diğer tipten daha yüksek olduğunu tespit etmișlerdir. Çalıșmada, ezme ünitesi içinde kullanılan paletlerin türü plastik olup, bu paletlerin ürünü birkaç yerinden narin bir șekilde ezmesinin yaprak kayıplarını azaltmıș olabileceği ve dolayısıyla protein oranının da bu nedenle artmıș olabileceği düșünülebilir. Kaba yemlerin protein değerlerinin yüksek olmasını amacıyla kullanılan baklagillerin HP miktarını artırdığı bilinmektedir. Çalıșmada da geleneksel olarak kullanılmakta olan FT karıșımı yerine ii önerilebilir. Bu durumda yaklașık olarak \%25 oranlarında ham protein oranında bir artıș olmaktadır.

Çizelge 3. Nispi yem değerine (NYD) ait varyans analizi.

Table 3. Variance analysis of relative feed value (RFV).

\begin{tabular}{|c|c|c|c|c|}
\hline & PARAMETRELER & $\begin{array}{c}\text { SKM } \\
(\%)\end{array}$ & $\begin{array}{l}\text { KMT } \\
(\%)\end{array}$ & NYD \\
\hline \multicolumn{5}{|c|}{ KARIȘIM } \\
\hline ii & & 56.93 & $2.18 a$ & $96.79 a(3)$ \\
\hline FT & & 57.20 & $2.12 \mathrm{~b}$ & $94.88 \mathrm{~b}(3)$ \\
\hline
\end{tabular}

HASAT TEKNIĞí- MUHAFAZA

\begin{tabular}{lccc} 
S1 & $54.89 \mathrm{~d}$ & $2.03 \mathrm{~d}$ & $86.96 \mathrm{~d}(4)$ \\
S2 & $57.16 \mathrm{c}$ & $2.16 \mathrm{bc}$ & $96.28 \mathrm{c}(3)$ \\
S3 & $58.82 \mathrm{~b}$ & $2.21 \mathrm{ab}$ & $101.02 \mathrm{~b}(3)$ \\
S4 & $60.42 \mathrm{a}$ & $2.25 \mathrm{a}$ & $105.83 \mathrm{a}(2)$ \\
S5 & $54.02 \mathrm{~d}$ & $2.11 \mathrm{c}$ & $89.08 \mathrm{~d}(3)$ \\
& 2.03 & 4.10 & 5.53 \\
\hline Karıșım (\%) & ÖD & $*$ & $*$ \\
Hasat tekniği-muhafaza & $* *$ & $* *$ & $* *$ \\
Karıșım x hasat tekniği & ÖD & $* *$ & $* *$ \\
ve muhazafa & & &
\end{tabular}

${ }^{*} p<0.05 ;{ }^{*} p<0.01$ hata sınırları içinde önemlidir, ÖD: Önemli değil;ii: İtalyan çimi + iskenderiye üçgülü karıșımı, FT: Fiğ + tritikale karıșımı; S1:Tamburlu ot biçme (Kuru ot), S2:Ezme üniteli diskli çayır biçme(Kuru ot), S3:Tamburlu ot biçme (Haylaj), S4:Ezme üniteli diskli çayır biçme (Haylaj), S5: Ot silaj (silaj); (1, 2, 3, 4, 5): kalite sınıfı 
Genel olarak, Çizelge 2 ve Çizelge 3 değerlendirildiğinde özellikle pH, ADF, NDF, SKM, KMT ve NYD üzerinde hasat tekniği ve muhafaza șartlarının $p<0.01$ önem seviyesinde, HP değeri üzerinde ise $p<0.05$ önem seviyesinde etkili olduğu belirlenmiștir. HP değerinin en düșük olduğu konuların S1 ve S2 olması beklenen bir durum olmasına rağmen, S1 konusunun protein değerinin S2 konusuna göre az olduğu belirlenmiștir. Bu durumun hasat makinalarının biçmiș olduğu ürünü yere bırakma șekli ile ilgili olduğu düșünülmektedir. Tamburlu ot biçme makinası ile hasat edilen ürün birbirinin üstüne sıkı bir șekilde örtünerek kurumuș ve rulo balya makinası ile silindirik kuru ot balyası yapılırken kullanılan küçük tip rulo makinasının çalıșma performansı olumsuz yönde etkilenmiștir.

Balya makinası kurumuș otu alırken zorlanmıș ve bitki üzerindeki yaprakların dökülmesine neden olmuștur. Yaprak kaybının artmasıyla birlikte HP miktarının da paralel olarak azalmıș olabileceği düșünülmektedir. Ezme üniteli diski çayır biçme makinası ile hasat edilen ürünlerde, ürün sap boyunca 3-4yerinden kırılarakyerekabarık birșekilde bırakılmıștır. Bu durumun rulo balya makinasının ürüne zarar vermeden, daha rahat bir biçimde çalıșmasına olanak sağladığı denemeler sırasında gözlemlenmiștir. HP miktarının, yaprak kayıplarının az olması durumunda yükseldiği düșünülmektedir. Elde edilen sonuçlar, yaprak kayıplarının protein miktarı üzerinde direkt etkisi olduğunu bildirin bazı çalıșmaların sonuçlarıyla da örtüșmektedir (Yaman ve Sönmezler, 2011). Denemede öne çıkan konu olan ezme üniteli diskli çayır biçme makinası ile ilgili Russell ve Johnson (2014) tarafından yapılmıș olan bir çalıșmada, her zaman için yapraklarda hazmolabilir protein ve karbonhidratlar saplara göre daha fazla olduğu ve yaprak kayıplarının önüne geçilmesinin yöntemlerinin aranması gerektiği bildirilmiștir. Hasat sırasında yaprak kayıplarının yașanması ile ürünün besleyicilik değerinin düștüğü ve bu kayıpların azaltılması için hasatta mutlak șartta șartlandırıcılı tip ot hasat makinalarının kullanımı tavsiye edilmektedir. Ayrıca Müller (2009) çalıșmasında, ürünlerin parçalanmadan haylaj halinde muhafaza edilmesiyle geleneksel silaja göre daha kaliteli ve hayvan sağlığı açısından da daha kullanıșlı ürün elde etmenin mümkün olduğunu bildirmiștir. Çalıșmasında, uzun saplı ve parçalanmadan muhafaza edilen kaba yemlerle beslenen hayvanların dıșkılarından örnekler alarak biyolojik açıdan incelemiș ve $\mathrm{pH}$ miktarının geleneksel silaj ile beslenen hayvan dıșkılarına göre bir miktar yüksek olsa bile hayvan sağlığı açısından risk teșkil etmeyeceğini belirlemiștir. Ayrıca çiğneme oranının bir miktar arttığı, ancak bulun tükürük salgısının artarak mide öz sIVISı pH seviyesini korumada olumlu olduğu da çalıșmada vurgulanmıștır.

\section{SONUÇLAR}

Çalıșmada, Çukurova Bölgesi iklim koșullarına uygun ve geleneksel silaja alternatif olabilecek kaliteli kaba yem hazırlamada hasat ve muhafaza sistemlerinin tespit edilmesi planlanmıștır. Bu doğrultuda, küçük ișletmeler için farklı kıșlık yem bitkisi karıșımlarına uygun olabilecek kaba yem hazırlama mekanizasyonu zinciri belirlenmiștir. Bu zincir, kıșlık kaba yem olarak ekilmesi planlanan karıșımın içeriği ile direkt ilgili olduğu deneme sonuçlarına göre söylenebilir. Bitkisel materyalin yapısal özellikleri, kullanılan makinaların çalıșma performansına etki ederek, ürün kalitesini ve verimini değiștirebilmektedir.

Muhafaza konuları olan kuru ot, haylaj ve geleneksel silaj konuları bir arada değerlendirildiğinde, ezme üniteli diskli çayır biçme makinası ile yapılan hasatlardan elde edilmiș haylajların, NYD bakımından diğer konulara göre istatistiki anlamda ve $p<0.05$ önem düzeyinde farklı olduğu belirlenmiștir. Tamburlu ot biçme makinası ile hasat edilerek haylaj yapılan ürünlerin, NYD'i düșüktür. Bu durumu, hasat makinalarının ürüne yapmıș olduğu etki ile değerlendirerek açıklamam mümkün olabilir. Ezme üniteli diskli çayır biçme makinası ile hasat edilen ürün, en az 3-4 yerinden kırmakta ya da ezmektedir. Ezilen materyalde mikroorganizmaların șekere hızla ulașması ile Süt Asidi Bakterilerinin faaliyetlerinin hızlandığı ve iyi koșullarda fermantasyon sürecinin oluștuğu söylenebilir. Bu etkinin, tamburlu hasat makinası ile hasat edilen üründe daha az olduğu deneme sırasında yapılan gözlemlerlede belirlenmiștir. Tamburlu hasat makinası ile hasat edilen ürünlerde ezilme ișlemi yapılmadığından, bitki bünyesi içindeki șekerin yeterince açığa çıkmaması, fermantasyon koșullarını bir miktar etkilemiș ve NYD'de düșmelere neden olduğu tahmin edilmektedir.

NYD bakımından en iyi kalite değerinde olan konudur. Benzer özelliklere sahip farklı yem bitkilerinde bu sistemin kullanılabilir olacağı 
söylenebilir. Bölge iklim koșulları için “Ezme üniteli diskli çayır biçme makinası + rulo balya makinası + rulo sarma makinası" kullanılarak \%45-60 KM içerikli ürünlerin haylaj olarak hazırlanması küçük ișletmelere tavsiye edilebilir.

\section{KAYNAKLAR}

Anonim (2002). Yarı otomatik protein cihazları kullanım klavuzları, TS 1620, TS 1727, TS 4500, 24.08.1974 Tarihli Resmi Gazete Yem Analiz Metotları Bölümü, Ankara, Nisan 2002.

Anonim (2016). Operator's manuel ankom 200/200 fiber analyzer. 2052 O'Neil Road, Macedon NY 14502. www. ankom.com.

Ball DM, Hoveland CS, Lacefield GD (1996). Forage quality in southern forages. Potash \& Phosphate Institute. Norcross, Georgia. Pp. 124-132.

Baytekin H, Gül i (2009). Yem bitkilerinde hasat, kuru ot üretimi, depolama ve silaj. Yem Bitkileri Genel Bölüm Cilt 1. Tarım ve Köy İșleri Bakanlığı Tarımsal Üretim ve Geliștirme Genel Müdürlüğü Yayınları, İzmir. pp. 121-140.

Bilgen $H$, Yalçın H, Özkul H, Cakmak B, Polat M, Kılıç A (2005). Plastik rengi, vakum uygulaması ve bekletme șeklinin paket mısır silaj yemi kalitesi üzerine etkileri. Ege Üniversitesi Ziraat Fakültesi Dergisi, ISSN 1018-8851, 42(2): pp 77-85.

DATAEM (2016). Doğu Akdeniz Tarımsal Araștırma Enstitüsü Müdürlüğü Çeșit Kataloğu. www.cukurovataem. gov.tr, Erișim: 08.08.2016

Kalaycı M (2005). Örneklerle jump kullanımı ve tarımsal araștırmalar için varyans analiz modelleri. Anadolu Tarımsal araștırma Enstitüsü Müdürlüğü Yayınları, Yayın No: 21, Eskișehir.

Kilıç A (2010). Silo yemi (öğretim-öğrenim ve uygulama örnekleri) el kitabı. Hasad Yayıncılık, İstanbul. P. 263.

Kutlu HR (2008). Yem değerlendirme ve analiz yöntemleri. Çukurova Üniversitesi Ziraat Fakültesi Zootekni Bölümü, Ders notları, Adana.
Kutlu HR (2009). Tüm yönleri ile silaj yapımı ve silajla besleme. Çukurova Üniversitesi Ziraat Fakültesi Zootekni Bölümü Seminer notları, Adana.

Mayouf R, Arbouche F (2014). Chemical composition and relative feed value of three mediterranean fodder shrubs. African Journal of Agricultural Research. 9 (8): pp. 746-749.

Müller CE (2009). Long-stemmed vs. cut haylage in baleseffects on fermentation aerobic storage stability, equine eating behaviour and characteritics of equine faeces. Animal Feed Science and Tecnology, Volume 152, Issue 3: pp. 307321.

Polak M, Jancovo M (2006). Effectiveness of conditioning herbage at harvesting. 12 th International Symposium Forage Conservation, Brno, Czech Republic, April 3-5, 2006. p. 186-189.

Russell MA, Johnson KD (2014). Selecting quality hay for horses. www.agry.purdue.edu./ext/forages/publications/id190.htm, Erișim tarihi: 11.12.2014.

Yaman S, Sönmezler C (2011). Balya silajı üretim tekniğinin geliștirilmesi. TÜBITAK Destekli Proje Sonuç Raporu, Proje No: $105 \mathrm{G} 086$

Yavuz M, İpsaș S, Ayhan V, Karadağ Y (2009). Yembitkilerinde kalite tayini ve kullanım alanları. Yembitkileri Kitabı. Tarım ve Köyișleri Bakanlığı Tarımsal Üretim ve Geliștirme Genel Müdürlüğü Yayınları, İzmir. Genel Bölüm. Cilt 1. Bölüm (5): p.163-172.

Yılmaz H, Gül M, Parlakay O, Akkoyun S, Bilgili ME, Vurarak Y, Kılıçalp N, Hızlı H (2015). Doğu Akdeniz Bölgesi süt sığırcılığı ișletmelerinin sosyo-ekonomik yapısı, sorunları ve çözüm önerileri. Gıda Tarım ve Hayvancılık Bakanlığı Tarımsal Araștırmalar ve Politikalar Genel Müdürlüğü Proje Sonuç Raporu, Proje No: TAGEM/TEAD/12/TE/000/009, Adana, p. 107, (Yayınlanmıș).

Yurtsever N (1984). Deneysel istatistik metodları. Tarım Orman Köyișleri Bakanlığı Köy Hizmetleri Genel Müdürlüğü Yayınları, Ankara, p.574. 